\title{
AgNOR polymorphism association with squamous intraepithelial lesions and invasive carcinoma with HPV infection
}

\author{
Luz del Carmen Alarcón-Romero, $\mathrm{PhD}^{(1,3)}$ Berenice Illades-Aguiar, $\mathrm{PhD}^{(1)}$ Eugenia Flores-Alfaro, $\mathrm{MSc}^{(1)}$ \\ Marco Antonio Terán-Porcayo, MSc ${ }^{(2)}$ Verónica Antonio-Véjar, MSc ${ }^{(1)}$ Elba Reyes-Maldonado PhD. ${ }^{(3)}$
}

\begin{abstract}
Alarcón-Romero LC, Illades-Aguiar B, Flores-Alfaro E, Terán-Porcayo MA,Antonio-Véjar V, Reyes-Maldonado E. AgNOR polymorphism association with squamous intraepithelial lesions and invasive carcinoma with HPV infection. Salud Publica Mex 2009;5 I:134-140.
\end{abstract}

\begin{abstract}
Objective. Evaluate the relationships between AgNORs polymorphisms and squamous intraepithelial lesions (SIL) and squamous cell carcinoma (SCC) with HPV infection. Materials and methods. A study was carried out on sixty women from the state of Guerrero, Mexico. HPV detection was performed by PCR.AgNORs were identified by argentic impregnation. One hundred cells per slide were counted and classified according to the polymorphism of AgNORs dots; typical (spherical) and atypical (large, kidney-shaped and clustered). Results.A total of $100 \%$ of the cases were positive for HPV infection. Nine different high-risk HPV genotypes were found, type 16 was the most common (48.6\%). The AgNORs showed a significant decrease in spherical shape according to neoplastic development. The three atypical shapes showed a significant increase in SIL and SCC (p-trend<0.00I). Conclusions.AgNORs polymorphism rises progressively according to the grade of histological lesions that can be useful as a prognosis for progression of SCC.
\end{abstract}

Keywords: nucleolar organizer regions, squamous intraepithelial lesions; human papillomavirus; squamous cell, carcinoma; Mexico
Alarcón-Romero LC, Illades-Aguiar B, Flores-Alfaro E, Terán-Porcayo MA, Antonio-Véjar V, Reyes-Maldonado E. Asociación de los polimorfismos AgNORs con lesiones intraepiteliales escamosas, carcinoma cervical e infección porVPH. Salud Publica Mex 2009;5 I:I34-I40.

\section{Resumen}

Objetivo. Evaluar la relación entre los polimorfismos de AgNORs con las lesiones intraepiteliales escamosas (LIE) y carcinoma de células escamosas (CCE). Material y métodos. Se estudiaron sesenta mujeres del estado de Guerrero, México. La detección delVPH fue por PCR y los AgNORs por impregnación argéntica; se contaron 100 células y se clasificaron por tipo de polimorfismo de AgNORs: típico (esférico) y atípicos (largo, forma de riñón o de racimo). Resultados. El $100 \%$ de los casos presentaron infección por VPH, se encontraron nueve genotipos diferentes de VPH de alto riesgo, el 16 fue el más común (48.6\%). La forma esférica de los polimorfismos de AgNORs mostró una disminución con el desarrollo neoplásico y las atípicas incrementaron progresivamente con SIL y SCC ( $p$-tendencia<0.00I). Conclusiones. Los polimorfismos AgNORs se incrementan progresivamente con el grado de lesión histológica, y pueden ser útiles en el pronóstico de progresión del carcinoma cervical.

Palabras clave: región organizadora del nucléolo; lesión intraepitelial escamosa, carcinoma de células escamosas; virus del papiloma humano; México

This work was supported by SIBEJ-CONACyT, Mexico (Grant 20005020159) and Coordinación General de Posgrado e Investigación del IPN, Mexico (Grant 2001049).

(I,3) Laboratorio de Citopatología y Biomedicina Molecular, Unidad Académica: Facultad de Ciencias Químico Biológicas, Universidad Autónoma de Guerrero. Chilpancingo, Guerrero, México.

(2) Instituto Estatal de Cancerología Dr.Arturo Beltrán Ortega. Acapulco, Guerrero, México.

(3) Laboratorio de Citología, Departamento de Morfología. Escuela Nacional de Ciencias Biológicas. Instituto Politécnico Nacional, México, DF, México. 
$\mathrm{I}_{\mathrm{cat}}^{\mathrm{n}}$ vasive cervical cancer is one of the most common cancers among women from developing countries. ${ }^{1}$ Incidence rates vary from 10 cases per 100000 women per year in many industrialized nations, to more than 40 per 100000 in some developing countries. ${ }^{2}$ In Mexico, invasive cervical cancer is the most common cancer among women. ${ }^{3}$ It is now well known that HPV infection plays a key role in cervical carcinogenesis. Some epidemiological and molecular studies report a worldwide HPV prevalence in cervical carcinoma of more than $95 \% .{ }^{4}$ Various types of HPV are associated with $90 \%$ to $100 \%$ of cervical cancers worldwide, and HPV 16 is detected in about $50 \%$ of them. ${ }^{5}$

HPV infection is a very common sexually transmitted disease among young women and it has been estimated that at least $50 \%$ of sexually active adults have had a genital HPV infection, but most infections are transient and resolve spontaneously in 6 to 24 months. ${ }^{6,7}$ Only a small percentage of HPV infections will lead to precursor cervical lesions and only those that persist long-term pose a risk for the development of cancer. ${ }^{6}$ HPV 16 is the most common type in SCC, but also in premalignant lesions ${ }^{8}$ such as HSIL, which are characterized by an increased mitotic rate, atypical mitotic figures and marked atypical nucleus in both superficial and basal epithelium. ${ }^{9}$

Nucleolar organizer regions (NORs) are loops of DNA that encode ribosomal RNA. DNA transcription and ribosomal RNA synthesis take place at these sites. Argyrophilic proteins associated with NORs are selectively identified by a silver colloid staining technique and visualized as dark, intranuclear dots under the optical microscope. ${ }^{10}$ Many authors have reported that the number of variations in argyrophilic nucleolar organizer regions (Ag NORs) reflects with some reliability the proliferative activity. ${ }^{11-13}$ It has also been shown that high AgNOR count, ${ }^{14}$ S-phase fraction and aneuploid DNA have prognostic significance in the early detection of cervical cancer. ${ }^{15}$ However, at present it has also been described that the increase in polymorphism of AgNORs in cervical biopsies could be used as a possible marker for histopathological diagnosis. ${ }^{16,17}$ Furthermore, only a few reports have been published concerning the variability of AgNORs in cervical cytology in women with cervical neoplastic damage, suggesting that polymorphism of AgNORs may be related to neoplastic development. Four AgNORs shapes have been quantified by Cortes-Gutierrez, et al ${ }^{18}$ for four groups of women with different grades of cervical neoplasm showing a progressive increase of atypical polymorphism in patients with HSIL and invasive carcinoma with respect to LSIL. The objective of the present work was to evaluate AgNORs polymorphism in LSIL, HSIL and SCC with HPV infection.

\section{Material and Methods}

We carried out a comparative study on sixty women from the state of Guerrero, Mexico, who were referred to the colposcopy service at the Dr. Arturo Beltran State Cancerology Institute between January and June of 2002. Women of all ages were included who had a diagnosis of SIL or SCC without previous treatment for these alterations and women with normal cytology and HPV negative. Insufficient samples were excluded as well as those that did not correspond to the squamocolumnar transformation zone. Fifteen of those presented LSIL, another $15 \mathrm{HSIL}, 15$ SCC and 15 were used as a control group with normal cytological. All groups included sexually active women of diverse ages without hysterectomies. The subjects received written and oral information before they gave their consent to participate. The study was performed in accordance with the Declaration of Helsinki and approved by the Ethics Committee of the University of Guerrero.

Specimen collection. Tissue samples were taken from colposcopically abnormal areas. Two fragments of tissue were taken; one was placed on $10 \%$ buffered neutral formol solution as a fixing agent for its later processing by the histological technique. The pathologist read the biopsy sections. The other tissue fragment was collected in a sterile eppendorff tube and placed quickly on dry ice for its further HPV detection and typing. The cytological material from the control group was collected from the ectocervix with an Ayre spatula and from the endocervix with a cytobrush, making sure that tissue from the transformation zone was taken. Smears were used for cytomorphological examination using conventional Papanicolaou. With the same brush, a second sample from the same region was taken and placed on $750 \mu \mathrm{l}$ of extraction solution (Tris $10 \mathrm{mM}, \mathrm{pH}$ 8.0, EDTA $20 \mathrm{mM}$, $\mathrm{pH}$ 8.0, SDS 0.5\%). For HPV detection, cy tobrushes with cervical scrapes were placed in lysis buffer $(10 \mathrm{mM}$ Tris $\mathrm{pH}$ 8.0, 20 mM EDTA pH 8.0 and $0.5 \%$ sodium dodecyl sulfate), were removed after taking out cervical material and stored at $-20^{\circ} \mathrm{C}$ until analysis.

Hematoxylin and eosin stain. Biopsies were processed by paraffin-embedded histological technique and three $\mu \mathrm{m}$ tissue sections were obtained; one of those was hematoxylin-eosin stained in order to do LSIL, HSIL and SCC diagnosis, and also to search for cytomorphological data of the HPV infection. The diagnosis was completed according to the Bethesda System classification. $H P V$ detection and typing. DNA was extracted according to the standard SDS-proteinase K-phenol-chloroform method. DNA samples were tested by the MY09/11 PCR protocol. ${ }^{19}$ The consensus primers MY09 and MY11 tar- 
get a conserved 450-pb region of the HPV L1 gene. The reaction mixtures $(50 \mu \mathrm{l})$ contained $1 \mu \mathrm{g}$ of target DNA, $0.8 \mu \mathrm{M}$ of each primer, $2 \mathrm{mM} \mathrm{MgCl}$, PCR buffer $1 X, 150$ $\mu \mathrm{M}$ of each dNTP and $1.25 \mathrm{U}$ of Ampli Taq Gold ${ }^{\mathrm{TM}}$. DNA was amplified in a GeneAmp PCR System 2400 (Applied Biosystems, Foster City, CA) with the following steps: a 10-min initial denaturation step at $95^{\circ} \mathrm{C}$, followed by 40 cycles of $95^{\circ} \mathrm{C}$ for $1 \mathrm{~min}, 58^{\circ} \mathrm{C}$ for $1 \mathrm{~min}, 72^{\circ} \mathrm{C}$ for 1 $\mathrm{min}$, and a final extension at $72^{\circ} \mathrm{C}$ for $10 \mathrm{~min}$. Integrity of DNA specimens was verified by amplification of a 268-bp region of the human $\beta$-globin gene using PC04 and $\mathrm{GH} 20$ primers.

For HPV typing, amplified PCR products were digested with restriction enzymes BamHI, DdeI, HaeIII, Hinfl, PstI, RsaI and Sau3AI and restriction fragment length polymorphism (RFLP) analyses were performed to identify more than 40 genital HPV types.

Silver-binding Argyrophilic Nucleolar Organized Regions (AgNORs). One tissue section was subjected to argentic impregnation with silver nitrate according to the procedure proposed by Ploton et al ${ }^{20}$ in 1986, counting the number and shape of the nucleolus under the optical microscope using 10x, 40x and 100x objectives in order to score the AgNORs. A lung adenocarcinoma section was used as a positive control. The same tissue was used as negative control without the addition of silver nitrate. The AgNORs were viewed as black dots in the nucleus. The number and polymorphism of AgNORs were counted in 100 cells for each slide with LSIL and HSIL (including the basal, parabasal and intermediate cell layers of the squamous epithelium), in pleomorphic cells from tumoral nests of SCC, in endocervical squamous metaplasia and in parabasal and cylindrical cells of cytological smears with reactive cellular changes associated with inflammation (Egan $e t$ al ${ }^{10}$ and Croker et $a^{12}$ ). The polymorphism of AgNORs was scored and classified according to its typical or atypical shape as shown in Figure 1. Typical shape was considered with spherical structure (A), atypical shapes are large (B), kidney-shaped (C) or clustered (D) structures as proposed by Cortes-Gutierrez et al. ${ }^{18}$

Statistical analysis. Data of the participants are reported as medians and interquartile ranges or percentages. Kruskall-Wallis test was used to assess the differences between median values for AgNORs polymorphism and the groups. Differences between the groups were measured using ANOVA with Bonferroni post test. The assessment of relationship between AgNORs polymorphism and health status was carried out through multiple linear regression model adjusted by age and HPV infection. Statistical analysis was performed using STATA software (V.9). P values $<0.05$ were reported statistically significant.

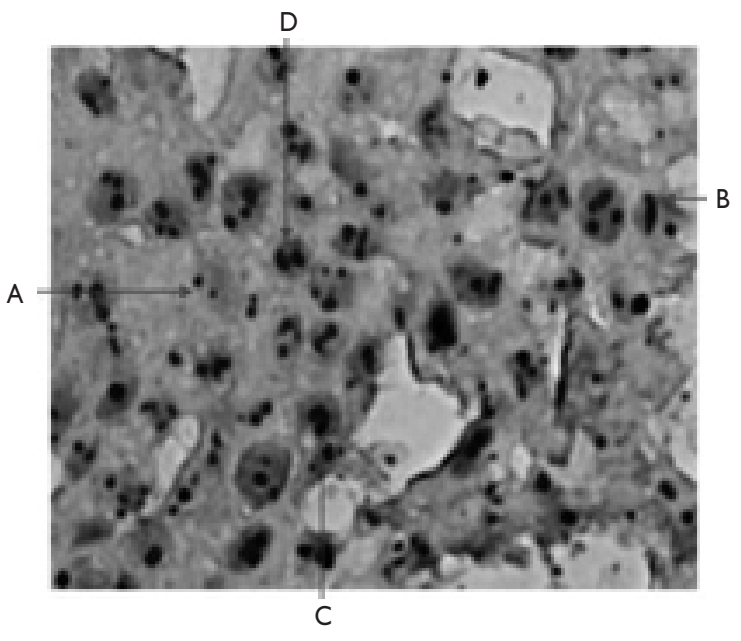

Figure I. Different types AgNORs in Cervical biopsy SPECIMEN ACCORDING TO SHAPE.TYPICAL:SPHERICIAL (A), ATYPICAL: LARGE (B), KIDNEY-SHAPED (C) AND CLUSTERED (D)

\section{Results}

\section{Histopathological study}

The patients' ages varied between 19 and 89 years with 33 being the median age for patients with LSIL, 38 for those with HSIL and 59 years for the SCC. The 15 LSIL cases included NIC 1 with pathognomonic koilocytes present in the superficial layer of the epithelium; the 15 HSIL presented koilocytes in parabasal and intermediate cell layers in NIC 2 and also included the superficial layer for NIC 3 . In contrast, the 15 SCC did not present koilocytes but were characterized by stroma invasion, tumoral nests, pleomorphism and nuclear hipercromasy. The control group had an average age of 38 years and the diagnosis was cytologies with reactive cellular changes associated with inflammation. In those samples no HPV DNA could be found by PCR.

\section{HPV detection and typing}

HPV infection was present in all SIL and SCC cases and none was found in normal cytology. In the 15 cases of LSIL the following HPV types in order of frequency were found: 16, 45, 52 and 69; a multiple infection and seven cases could not be described. With respect to the 15 HSIL, the HPV types found were: 31, 16, 18, 33, 35, 52,58 and 3 non-characterized cases. Of the 15 SCC, the HPV types found in order of frequency were: 16, 18, 31 
and 58. The most common HPV type found in LSIL was $16(20 \%)$, in HSIL type $31(26.6 \%)$ and in SCC type 16 $(66.6 \%)$, (table I).

\section{AgNORs polymorphisms}

The spherical AgNORs shape was the most frequent for normal cytology, LSIL and HSIL groups, and the large shape was the least frequent for all of them, although in the spherical form there was a decrease in median value, with an increase of malignancy to 80 in the LSIL group, 60 in the HSIL group, and 27 in SCC. There was a median increase for the large AgNORs of 2 to 11, kidney shaped of 20 to 36 and clustered of 3 to 25 structures from LSIL to SCC $(p<0.001)$. On the other hand, the median obtained for all atypical AgNORs groups increased to 27 in LSIL, 41 in HSIL and 73 in SCC. When making group-to-group comparisons of mean increases in atypical forms, to evaluate in which group these increases were larger, all the comparisons have a $p$-value $<0.001$ showing, as mentioned before, that as the lesion progresses the atypical forms increase significantly (table II).

To compare the viral types with the different forms of the AgNORs, they were stratified into HPVs 16, 18 and others; the results show significant differences

Table I

Frequency of HPV genotypes IN THE POPULATION Studied. State of Guerrero, MeXico, 2000-200 I

$$
\text { Factor } \quad \begin{array}{cccc}
\text { NC } & \text { LSIL } & \text { HSIL } & \text { SCC } \\
n=15 & n=15 & n=15 & n=15
\end{array}
$$

Age (y) mean (rank) $38(19-63) \quad 33(19-56) \quad 38(19-63) \quad 59(35-89)$

\begin{tabular}{lcccc}
$\begin{array}{l}\text { Viral genotype } \mathrm{n}(\%) \\
\text { Negative }\end{array}$ & $\mathrm{I} 5(\mathrm{I00})$ & 0 & 0 & 0 \\
\hline 16 & -- & $3(20)$ & $3(20)$ & $\mathrm{I0}(66.6)$ \\
\hline 18 & -- & -- & $\mathrm{I}(6.7)$ & $3(20)$ \\
\hline 31 & -- & -- & $4(26.6)$ & $\mathrm{I}(6.7)$ \\
\hline 33 & -- & -- & $\mathrm{I}(6.7)$ & -- \\
\hline 35 & -- & -- & $\mathrm{I}(6.7)$ & -- \\
\hline 45 & -- & $2(13.3)$ & -- & -- \\
\hline 52 & -- & $\mathrm{I}(6.7)$ & $\mathrm{I}(6.7)$ & -- \\
\hline 58 & -- & -- & $\mathrm{I}(6.7)$ & $\mathrm{I}(6.7)$ \\
\hline 69 & -- & $\mathrm{I}(6.7)$ & -- & -- \\
\hline Multiple infection & -- & $\mathrm{I}(6.7)$ & -- & -- \\
\hline HPV-x & -- & $7(46.6)$ & $3(20)$ & --
\end{tabular}

NC: Normal cytology; LSIL: low-grade squamous intraepithelial lesion; HSIL high-grade squamous intraepithelial lesion; SCC: squamous cervical carcinoma
Table II

AGNOR POLYMORPHISM DOTS IN THE FOUR STUDY groups. State of Guerrero, Mexico, 2000-200I

AgNors
polymorphism (\%) NC LSIL $\quad$ HSIL $\quad$ SCC $\quad$ p value*

\begin{tabular}{lccccc} 
Spherical & 100 & $80(63-87)$ & $60(49-63)$ & $27(20-35)$ & $<0.00$ I \\
\hline Large & -- & $2(0-5)$ & $5(2-8)$ & $1 \mathrm{II}(10-15)$ & $<0.00 \mathrm{I}$ \\
\hline Kidney-shaped & -- & $20(10-25)$ & $25(20-30)$ & $36(30-40)$ & $<0.00 \mathrm{I}$ \\
\hline Clustered & -- & $3(1-7)$ & $15(10-18)$ & $25(20-30)$ & $<0.00 \mathrm{I}$ \\
\hline Atypical & -- & $27(14-35)$ & $4 \mathrm{I}(37-53)$ & $73(65-80)$ & $<0.00 \mathrm{I}$
\end{tabular}

NC: Normal cytology; LSIL: low-grade squamous intraepithelial lesion; HSIL highgrade squamous intraepithelial lesion; SCC: squamous cervical carcinoma

Data are median (25th-75th percentile)

* Kruskal-Wallis test

Table III

AGNOR POLYMORPHISM DOTS BY HIGH-RISK HPV in the population studied. State of Guerrero, MeXico, 2000-200I

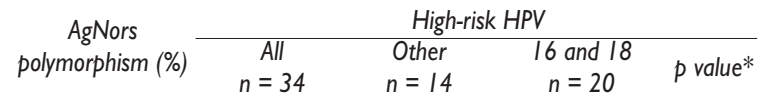

\begin{tabular}{lllll} 
Spherical & $45(28-6 \mathrm{I})$ & $60(57-69)$ & $33.5(25-47.5)$ & $<0.00 \mathrm{I}$ \\
\hline Large & $8.5(5-10)$ & $5(\mathrm{I}-5)$ & $10(8-\mathrm{II} .5)$ & $0.00 \mathrm{I}$ \\
\hline Kidney shaped & $30(25-35)$ & $25(20-30)$ & $33.5(29-40)$ & $0.00 \mathrm{I}$ \\
\hline Clustered & $15(10-25)$ & $10(3-15)$ & $20(15-29)$ & 0.002 \\
\hline Atypical & $55(39-72)$ & $40(30-43)$ & $66.5(52.5-75)$ & $<0.00 \mathrm{I}$
\end{tabular}

between the median values (table III). However, when these same comparisons were carried out by group, the p-values were 0.28 for LSIL, 0.03 for HSIL and 0.12 for SCC. Multiple linear regression models showed that $96 \%$ of variability of AgNORs is explained by SIL and SCC with gradual increases ( $\mathrm{p}$-trend $<0.001$ ) (table IV).

\section{Discussion}

The age range in women presenting SCC was between 35 and 89 years with a median age of 59 , which compares to results reported in other studies where this carcinoma appears in women of ages between 40 and 60 years. ${ }^{21}$ In studies by other Mexican researchers carried out in non selected populations, as is our case, two incidence peaks of high-risk HPV infection have been found, one in the age group between 15-19 with a frequency of 25\% and another in women aged between 56-65 with a 5.3\% frequency; therefore it has been proposed that incidence 
Table IV

EFFECT OF SQUAMOUS INTRAEPITHELIAL LESIONS

OF LOW-GRADE, HIGH-GRADE AND SQUAMOUS CERVICAL CARCINOMA ON COUNT AGNOR POLYMORPHISM

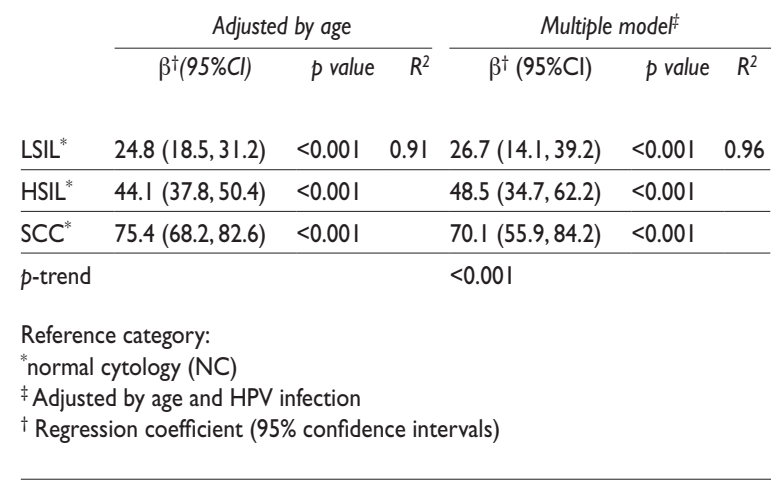

declines along with age. ${ }^{22}$ In this study, the cases with HPV infection were found in women from ages 19 for the LSIL to 63 years for HSIL, while the age range for the SCC figured between 35 to 89 years.

HPV DNA was detected in all cases included in this study which confirms what has already been proposed by other researchers, the fact that HPV DNA has been detected in more than $95 \%$ of the SIL and SCC. ${ }^{4}$ In $75.6 \%$ of all analyzed cases, it was possible to determine the HPV types present; all HPV types found were high-risk. HPV types 16, 31 and 18, followed by 45, 52, 58, 33, 35 and 69 were the most frequently detected. This is very relevant because most of them correspond to the seven most frequently reported HPV types in cervical carcinoma.

We also found that the frequency of HPV types is not the same in premalignant lesions and SCC. For LSIL, HPV 16 was the most common type found, followed by HPV type 45 and multiple HPV infection, considered by some researchers as associated with $\mathrm{HSIL}^{23,24}$ and adenosquamous carcinoma. ${ }^{25}$ In seven of these cases, viral DNA was found but no characterization was possible. In five of these cases the presence of scarce koilocytes was found by histological analysis which implies the fact that the tissue processed by PCR did not possess enough viral DNA for its amplification. In the HSIL, HPV types 31,16 and 18, in that order, were the most frequently found. Interestingly for this group, HPV 31 was the most commonly detected type, even more than HPV 16 , although this viral type is frequently found in the American population ${ }^{26}$ and is included in the high-risk HPV types associated with cervical carcinoma etiology (notably 16, 18, 31 and 45). ${ }^{26-28}$ The prevalence of the viral types varies according to the geographic region and detection of the high-risk types in premalignant lesions suggest that a more accurate control and following of these patients should be made.

In relation to SCC cases, HPV type 16 was the most frequently found, followed by type 18 . These results are in accordance with those reported by other studies that show that HPV 16 is the most frequently found in SCC, with $50 \%$ of the cases being positive, which is higher than values reported by other studies, although the number of cases in this study is small. In another study done in the state of Guerrero, Mexico by Illades et. $\mathrm{al}_{1}{ }^{29}$ they found that $97.7 \%$ of SCC were related to HPV infection, where $51 \%$ of those presented HPV type 16 and the most frequently found types were 16, 18, 31 and 33. It has to be noted that in Mexico, the prevalence of HPV infection studies are scarce and they all report HPV 16 as being the most frequently found. ${ }^{30,31}$

Different researchers have described the use of the AgNORs technique to determine the proliferative activity in several pathologies and it is considered that the quantity and polymorphism of AgNORs dots are related with this activity; ${ }^{32-34}$ thus, its determination has been widely used in the study of both premalignant ${ }^{14,35-38}$ and malignant uterine cervix lesions. ${ }^{32-35}$ Unfortunately, there are few studies that relate this parameter not only with the presence of $\mathrm{HPV}^{10,32,38}$ but with the viral types. Our results showed a progressive increase in atypical AgNORs according to neoplastic development. Atypical polymorphism showed a significant increase in patients with LSIL, HSIL and SCC. This increase may be explained by the relationship between morphological changes in the AgNORs and high transcriptional activity due to proliferative potential, increased activity of rRNA genes, ploidy and aneuploid DNA ${ }^{15,39}$ or infection of the cells with $\mathrm{HPV}^{40}$ In this work, all samples were infected with high-risk HPV types. On the other hand, we counted the number and polymorphism of AgNORs and this polymorphism provides us with information about the behavior of the cell. In this study, the high number of large, kidney shaped and clustered AgNORs observed in women with LSIL, HSIL and SCC was associated with malignant transformation probably due to HPV infection. The results presented here show that as the severity of the histopathological lesion progresses, the number and polymorphism of AgNORs increases and the highest number was found in SCC cases. These data are similar to and corroborate those found by Egan et al, in $1988^{10}$ and Prathiba et al, in $1995,{ }^{38}$ who also reported significant differences in the AgNORs counts and the premalignant and malignant lesions in uterine cervix.

The AgNORs are a cellular proliferative activity marker useful in the evaluation of hard-to-diagnose lesions, mainly in those that have a borderline behavior. However, to distinguish the differences between low 
and high grade lesions, the pathologist has to have a careful control of the colloidal silver stain and the histological technique; it is known that it is necessary to repeat the staining various times due to the high risk of silver precipitation, as well as making sure that the histological cuts are three microns thick, otherwise the clarity and ease of counting of the AgNORs polymorphism is compromised.

Additionally, in previous works HPV infection has only been related to the AgNORs quantity and the lesion degree, but it has not been related to viral types since only koilocyte presence has been taken as a parameter of viral infection. In this study, when comparing HPV types 16 and 18 with other high-risk viral types with different forms of AgNORs, significant differences were found, indicating that during the progression of the lesion HPV induces a progressive increase in cellular proliferation. On the other hand, there were no important differences when making these same comparisons between the groups of women studied, which shows that the presence of atypical AgNORs shapes are a product of cellular alterations that are clearly related to not only the viral integrations into the infected cell's DNA but also to the progression of the lesion and the strong relationship that exists between viral types 16 and 18 and cancer of squamous cells, recognized as highly aggressive types.

Our results suggest that a compound study of viral parameters, such as the viral type along with cellular proliferation markers such as the polymorphism of AgNORs can be useful as prognosis factors to estimate the progression of premalignant lesions to SCC.

\section{References}

I. Zur Hausen H. Papillomaviruses and cancer: from basic studies to clinical application. Nat Rev Cancer 2002;2(5):342-350.

2. Parkin DM, Pisani P, Ferlay J. Estimates of the worldwide incidence of 25 major cancers in 1990. Int J Cancer 1999;80:827-841.

3. Lazcano-Ponce EC, Rascon-Pacheco RA, Lozano-Ascencio R, VelascoMondragón HE. Mortality from carcinoma of the uterine cervix in Mexico: impact of screening 1980-1990. Acta Cytol 1996;40:506-512.

4. Walboomers JM, Jacobs MV, Manos MM, Bosch FX, Kummer JA, Shah $\mathrm{KV}$, et al. Human papillomavirus is a necessary cause of invasive cervical cancer worldwide.J Pathol 1999;189:12-9.

5. Bosch FX, Manos MM, Muñoz N, Sherman M, Jansen AM, Peto J, et al. Prevalence of human papillomavirus in cervical cancer: a worldwide perspective. International biological study on cervical cancer (IBSCC) Study Group.J Natl Cancer Inst 1995; 87:796-802.

6. Franco EL,Villa LL, Ruiz A, Costa MC. Transmission of cervical human papillomavirus infection by sexual activity: differences between low and high oncogenic risk types.J Infect Dis 1995;172:756-763.

7. Kjellberg L, Hallmans G,Ahren AM, Johansson R, Bergman F,Wadell G, et al.Smoking, diet, pregnancy, and oral contraceptive use as risk factors for cervical intraepithelial neoplasia in relation to human papillomavirus infection. Br J Cancer 2000;82:1332-1338.

8. Schiffman MH, Bauer HM, Hoover RN, Glass AG, Cadell DM, Rush $\mathrm{BB}$, et al. Epidemiological evidence showing that human papillomavirus infection causes most cervical intraepithelial neoplasia. J Natl Cancer Inst (Bethesda) 1993;85:958-964.

9. Koutsky LA, Holmes KK, Critchlow CW, Stevens CE, Paavonen J, Beckmann AM, et al.A cohort study of the risk of cervical cancer intraepithelial neoplasia grade 2 or 3 in relation to papillomavirus infection. N Engl J Med 1992: 327:1272-1278.

I0. Egan M, Freeth M, Crocker J. Intraepithelial neoplasia, human papillomavirus infection and argyrophilia nucleoprotein in cervical epithelium. Histopathology 1988;13:561-567.

II. Cardillo MR. AgNOR counts are useful in cervical smears. Diagn Cytopathol 1992;8:208-210.

12. Crocker J, Boldy AR, Egan MJ. How should we count AgNORs? Proposal for a standardized approach.J Pathol 1989;158:185-188. 13. Rocher AE, Gonzalez A, Palaoro LA, Blanco AM. Usefulness of AgNOR technique and CEA expression in atypical metaplastic cells from cervical smears. Anal Quant Cytol Histol 2006;28:130-136.

14. Misra JS, Das V, Srivastava AN, Singh U, Singh M. AgNOR counts in cervical smears under normal and other cytopathologic conditions. Anal Quant Cytol Histol 2005;27:337-340.

15. Singh M, Prasad S, Kalra N, Singh U, Shukla Y. Silver-Stained Nucleolar Organizer Regions in normal and and dysplastic cervical lesions: Correlation with DNA ploidy and S-phase fraction by flow cytometry. Oncol 2006;7I:4II-4I6.

16. Agarwal J, Gupta JK. Nucleolar organizer regions in neoplastic and non-neoplastic epithelium of the cervix. Indian J Pathol Microbiol 1997;40:125-I27.

17. Calore EE, Maeda MYS, Cavaliere MJ. Study of nucleolar organizer regions by the argyrophil technique in cervical intraepithelial neoplasia. Minerva Ginecol 1997;49:59-62.

18. Cortes-Gutierrez El, Leal-Elizondo EM, Cerda-Flores RM, Leal-Garza $\mathrm{CH}$. Polymorphism of $\mathrm{Ag}^{+}-\mathrm{NORs}$ in cervical smears from women with cervical cancer.Analyt Quant Cytol Histol 200I; 23:9-14.

19. Bernard HU, Chan SY, Manos MM, Ong CK, Villa LL, Delius H, et al. Identification and assessment of known and novel human papillomaviruses by polymerase chain reaction amplification, restriction fragment length polymorphisms, nucleotide sequence, and phylogenetic algorithms. J Infect Dis 1994; 174:1077-1085.

20. Ploton D, Menager M, Jeannesson P, Himber G, Pigeon F,Adnet JJ. Improvement in the staining and in the visualization of the argyrophilic protein of the nucleolar organizer region at the optical level. Histochem J 1986; 18:5-14.

21. Verduzco-Rodriguez L, Palet-Guzmán JA,Aguirre-González H, González-Puebla E. Cáncer cervico-uterino y edad. Ginecol Obstet Mex 1997; 5: I 19-122.

22. Lazcano-Ponce E, Herrero R, Muñoz N, Cruz A, Shah KV,Alonso P, et al. Epidemiology of HPV infection among Mexican women with normal cervical cytology. Int J Cancer 2001;91:4I2-420.

23. Sasagawa T, Basha W, Yamazaki H, Inouse M. High-risk and multiple human papillomavirus infections associated with cervical abnormalities in Japanese women. Cancer Epidemiol Biomarkers Prev 200 I; 10:45-52. 24. Van der GraafY, Molijn A, Doornewaard H, Quint W,Van Doorn LJ, Van Den Tweel J. Human papillomavirus and the long-term risk of cervical neoplasia. Am J Epidemiol 2002;156:I58-164.

25. Schellekens MC, Dijkman A,Aziz MF, Siregar B, Cornain S, KolkmanUljee $S$, et al. Prevalence of single and multiple HPV types in cervical carcinomas in Jakarta, Indonesia. Gynecol Oncol 2004;93:49-53.

26. Muñoz N, Bosch FX, de Sanjosé S, Herrero R, Castellsagué X, Shah KV, et al. Epidemiologic classification of human papillomavirus types associated with cervical cancer. N Engl J Med 2003;348:5 18-527. 
27. Giuliano AR, Papenfuss M,Abrahamsen M, Denman C, de Zapien JG, Henze JL, et al. Human papillomavirus infection at the United StatesMexico border: Implications for cervical cancer prevention and control. Cancer Epidemiol Biomarkers Prev 2001;10:1 129-1 I36.

28. Klaes R, Woerner SM, Ridder R, Wentzensen N, Duerst M, Schneider $A$, et al. Detection of high-risk cervical intraepithelial neoplasia and cervical cancer by amplification of transcripts derived from integrated papillomavirus oncogenes. Cancer Res 1999;59:6132-6136.

29. Illades-Aguiar B, Leyva-Vazquez M,Alarcon-Romero L, Flores-Alfaro E, Antonio-Vejar V, Lopez-Zamudio N, et al. Human papillomavirus infection in Mexican women with cervical cancer, squamous intraepithelial lesion and cytologically normal. Abstract \#93. Barcelona, Spain: $18^{\text {th }}$ International Papillomavirus Conference, July 2000.

30. Ordoñez-Razo RM, Mendoza-Alcantár L, Reynoso-Pablos R, SolorzanoLuna G, Ramírez-Gaytán JL, Meneses-García A, et al. Papilomavirus humano en pacientes con cáncer cervicouterino en el Instituto Nacional de Cancerología. Rev Inst Nal Cancerol 1993;39:1809-1813.

31. Hernández-Avila M, Lazcano-Ponce EC, Berumen-Campos J, CruzValdéz A,Alonso de Ruíz PP, González-Lira G, et al. Human papillomavirus 16-18 infection and cervical cancer in Mexico: a case-control study.Arch Med Res 1997;28:265-71.

32. Khanna AK, Giri AK, Khanna A, Kumar M. Nucleolar organizer region count and subjective $A g N O R$ pattern assessment (SAPA) score in skin tumors. J Sur Oncol 200 I;78:273-278.
33. Dervan PA, Gilmartin L, Loftus BM, Carney DN. Breast carcinoma kinetics. Argyrophilic nucleolar organizer region counts correlate with Ki67 score. Am J Clin Pathol 1989;92:40I-407.

34. Cabrini RL, Schwint AE, Mendez A, Femopase F, Lanfranchi H, Itoiz ME. Morphometric study of nucleolar organizer regions in human oral normal mucosa, papilloma and squamous cell carcinoma.J oral Pathol Med 1992;21: 275-279.

35. Rowlands DC. Nucleolar organising regions in cervical intraepithelial neoplasia.J Clin Pathol 1988;4I:I200-1202

36. Calore EE, Maeda MY, Cavaliere MJ, Pereira SM, Shih LW, Pereira GM, et al. Study of organizer nucleolar regions by the argyrophil technique in cervical intraepithelial neoplasias. Minerva Ginecol 1997;49:59-62.

37. Pelusi G, Trerè D, Formelli G, Rinaldi AM, Derenzini M.AgNOR protein quantity of cervical smears correlates with that of histological sections in cervical intraepithelial neoplasia. Eur J Histochem 1997;4I:I05-I I0.

38. Prathiba D, Kuruvilla S.Value of AgNORs in premalignant and malignant lesions of the cervix. Indian J Pathol Microbiol 1995;38: II-I6.

39. Palaoro LA, Blanco AM, Gamboni M, Rocher AE, Rotenberg RG. Usefulness of ploidy $A g N O R$ and immunocytochemistry for differentiating benign and malignant cells in serous effusions. Cytopathol 2007;18:33-39. 40. Thickett KM, Griffin NR, Griffiths AP,Wells M.A study of nucleolar organizer in cervical intraepithelial neoplasia and human papillomavirus infection.Am J Obstet Gynecol 1989;8:33I-339. 